\title{
SHIELDING PERFORMANCE OF A NEWLY DESIGNED TRANSPORT CASK IN THE ADVANCED CONDITIONING SPENT FUEL PYROPROCESS FACILITIY
}

\author{
CHANG JE PARK*, CHANG JOON JEONG, DEOK KI MIN, HEE YOUNG KANG, WOO SEOK CHOI, \\ JOO CHAN LEE, GYEOUNG SIK BANG and KI SEOG SEO \\ Korea Atomic Energy Research Institute \\ 150 Deokjin-dong, Yusong-gu, Daejeon 305-353, Republic of Korea \\ "Corresponding author. E-mail : cjpark@kaeri.re.kr
}

Received December 10, 2007

Accepted for Publication April 8, 2008

To transport process wastes efficiently from the Advanced Spent Fuel Conditioning Pyro-process Facility (ACPF) at the Korea Atomic Energy Research Institute (KAERI), a new hot cell cask has been designed based on an existing hot cell padirac transport cask, with not only a neutron absorber for improved shielding capability, but also a docking facility for an easy docking system. In the new hot cell cask, two kinds of materials have been considered as shielding materials, polyethylene and resin. To verify the transport compatibility of the waste and spent fuel for the ACPF, neutron and photon shielding calculations were performed using the MCNPX code. The source term was evaluated by the ORIGEN-ARP code system based on spent PWR fuel. From the calculation, it was found that the maximum surface dose rates of the hot cell cask with the two candidates were estimated within the limit $(2 \mathrm{mSv} / \mathrm{hr})$.

KEYWORDS : ACPF, Transport Cask, Shielding Calculation

\section{INTRODUCTION}

When pyroprocessing spent nuclear fuel, oxide fuel is transformed into a metallic state from electrolysis such as electrolytic reduction, refinement, and winning. During such a process, a uranium oxide with fission products is chopped into pieces and placed in a basket which is lowered into a liquid salt solution. After a complicated dissolution process, $\mathrm{U}, \mathrm{Pu}, \mathrm{Th}$, rare earth, and other like oxides are separated [1]. To obtain basic technology to demonstrate the pyroprocess for spent nuclear fuel, a labscale ACPF was constructed in 2005 to accommodate a $20 \mathrm{kgHM} / \mathrm{batch}$. Remote operation and maintenance as well as interface systems between the process steps were considered in the design of the ACPF. A performance evaluation of the process systems including their neutron detection ability is under way [2].

To transport up to a $20 \mathrm{kgHM} /$ batch of the spent fuel in the ACPF, a new hot cell cask was devised. The conceptual design was based on an existing padirac cask [3] which is commercially used and has a capacity of about $10 \mathrm{kgHM} / \mathrm{batch}$ of spent fuel. Thus, the main design features of the new hot cell cask are enlargement of the transport capacity as well as easy access to a hot cell wall. To estimate the shielding capability of a storage and transport cask for spent fuel the Monte Carlo method is widely applied [4]. In this study, the shielding capability of the new hot cell cask was evaluated with the MCNPX code [5]. Furthermore, the shielding capabilities of two kinds of neutron absorbers, polyethylene and resin, were compared to obtain sufficient transportability and shielding effects.

In Section 2, the design features of the main transport casks are described, and the source term calculation is given in Section 3. The Monte Carlo analysis is provided in Section 4, and Section 5 provides the main results of the shielding calculation for the two kinds of neutron absorbers for the hot cell cask. Finally, the conclusion is presented in Section 6.

\section{DESIGN FEATURES OF THE NEW HOT CELL CASK}

There are many components installed in the Advanced Spent Fuel Conditioning Process Facility (ACPF). Among them, there are slitting devices for spent fuel, a voloxidizer to obtain spent fuel power, and an electro-refiner, a smelter, and a waste salt conditioner to process the spent fuel 


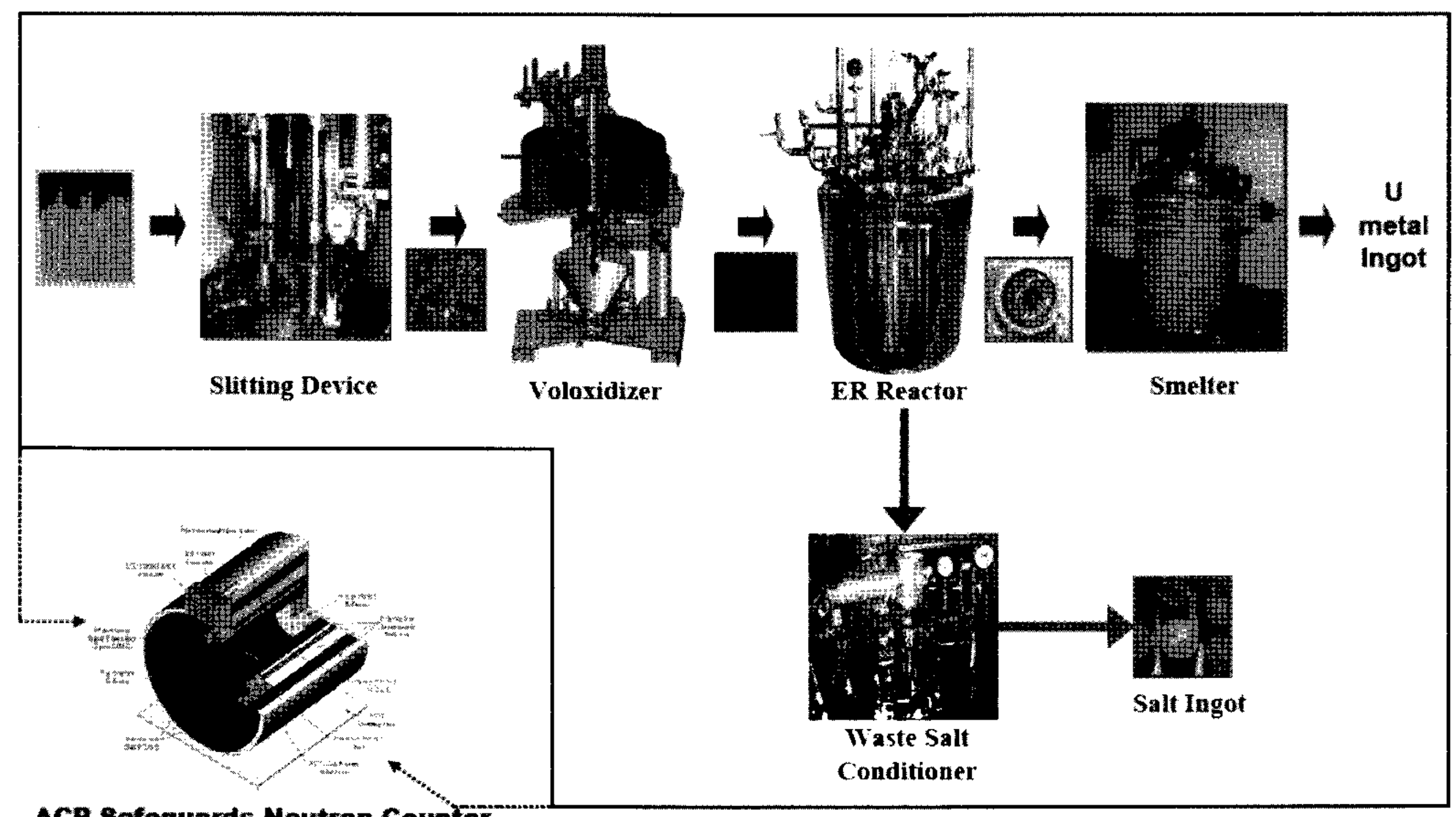

Fig. 1. Main Systems of the ACPF

components. The final stage for the spent fuel is a uranium metal ingot and a salt ingot. Fig. 1 depicts the main systems of the ACPF.

This process creates waste in metallic and ceramic forms of spent fuel; thus, to transport this process waste effectively, the capacity of the process was increased up to a $20 \mathrm{kgHM} / \mathrm{batch}$. To accommodate this requirement, a new hot cell transport cask has been designed, and it included a good connection mechanism to a hot cell wall. Fig. 2 shows the conceptual design for the new hot cell cask. It was designed to contain $20 \mathrm{kgU}$, which corresponds to about 65 rod cuts. The cask weight was designed to be around 3.8 ton to allow for sufficient transportability and an outer neutron shield was included in the design to

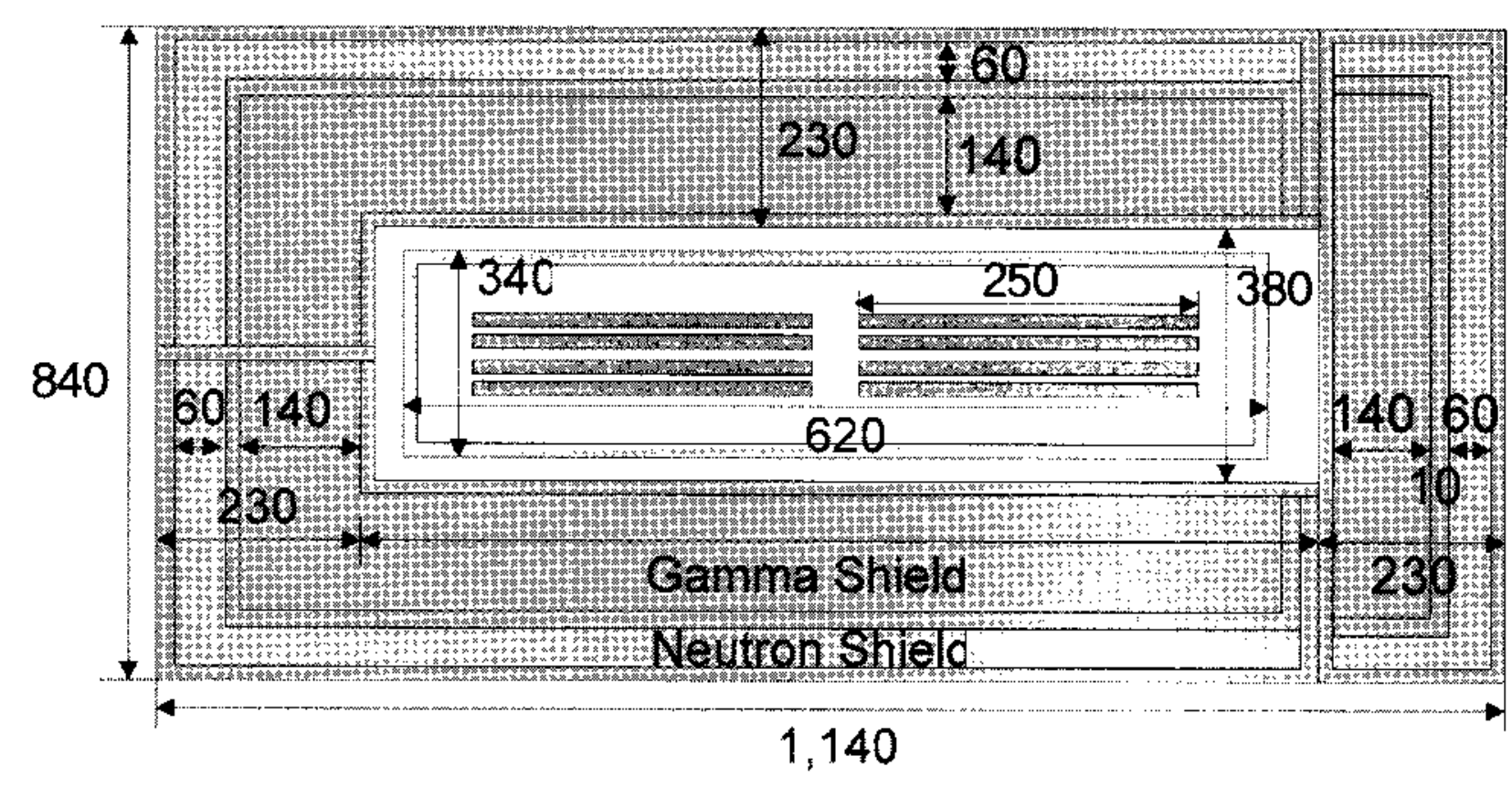

Fig. 2. Design Concept of the New Hot Cell Cask (unit:mm) absorb any external shock. Furthermore, the outer neutron shield provides neutron shielding with sufficient efficiency, and it also maintains the weight of the transport cask light when compared to the design of the inner neutron shield. In this study, polyethylene and resign were considered. The detailed material compositions of the shielding materials are given in Table 1.

Table 1. Composition of the Neutron Shield Materials for the New Hot Cell Cask

\begin{tabular}{l|c|c}
\hline & Polyethylene & Resin \\
\hline Density $\left(\mathrm{g} / \mathrm{cm}^{3}\right)$ & 0.93 & 1.43 \\
\hline & H: 14.3 & H: 7.0 \\
Composition (wt\%) & C: 85.7 & C: 37.4 \\
& & O: 55.6 \\
\hline
\end{tabular}

\section{SOURCE TERM ANALYSIS}

The source term for transporting spent fuel was chosen from a $17 \times 17$ array of PWR fuel with an enrichment of $4.5 \mathrm{wt} \%$. The average burnup of the spent 
fuel was given as $55 \mathrm{GWd} / \mathrm{tU}$ and the cooling time was set at 5 years. The ORIGEN-ARP code [6] was used to estimate the inventories and the activities of the spent fuel. Both the ENDF-V 44 neutron energy groups (44GrpENDF5) and the 18 photon energy groups (18GrpSCALE) libraries were used for the depletion calculations. Table 2 shows the inventories of the source term for the element type, and Table 3 shows the activities of the source term. The total activities of the fuel and irradiated cladding after a 5 year cooling-period were estimated as $6.719 \mathrm{E}+14 \mathrm{~Bq}$ and $4.200 \mathrm{E}+11 \mathrm{~Bq}$, respectively. Tables 4 and 5 show the neutron and gamma energy distributions for the source term, respectively. The total neutron and gamma ray sources were obtained as $2.496 \mathrm{E}+07$ neutrons/sec and $3.360 \mathrm{E}+14$ photons/sec, respectively.

\section{MONTE CARLO ANALYSIS}

Both a deterministic approach and a stochastic approach were used to solve the Boltzmann transport equation. The discrete ordinates method, which is a deterministic approach, transforms the continuous form of the Boltzmann transport equation into the discrete variables, such as the spatial variables expressed as finite intervals, the energy variables as energy groups, and the direction variables as discrete directions [7]. The Monte Carlo method, a stochastic approach, is one of the most powerful numerical methods available for solving neutron and photon transport phenomena [8].

In order to obtain the dose rate of the shielding rates, an MCNPX calculation was performed using a threedimensional model. The MCNPX three-dimensional model of the new hot cell cask was prepared by setting a finite cylinder along the $\mathrm{Z}$ axis. The width of the stainless steel cylinder, which contains neutron and gamma shield materials, is $1 \mathrm{~cm}$ for both the $\mathrm{Z}$ and $\mathrm{R}$ directions. The neutron and gamma fluxes are estimated for the outermost surface using the surface flux tally (F2) of the MCNPX standard neutron and gamma tally options. The tally segment card (FS) is also used to obtain a distribution of the neutron and gamma fluxes for various sub-cells of the top, bottom, and side surfaces. The user-specified dose

Table 2. Inventories of the Major Elements for the Source Term (PWR 4.5 wt\%, $55 \mathrm{GWd} / \mathrm{tU}, 5$ year cooling, $20 \mathrm{~kg}$ )

\begin{tabular}{lcccc}
\hline & Element & Weight $(\mathrm{g})$ & Element & Weight $(\mathrm{g})$ \\
\hline \multirow{4}{*}{ Fuel } & $\mathrm{O}$ & $2.689 \mathrm{E}+03$ & $\mathrm{Xe}$ & $1.782 \mathrm{E}+02$ \\
& $\mathrm{U}$ & $1.859 \mathrm{E}+04$ & $\mathrm{Nd}$ & $1.342 \mathrm{E}+02$ \\
& $\mathrm{Pu}$ & $2.423 \mathrm{E}+02$ & $\mathrm{Cs}$ & $8.371 \mathrm{E}+01$ \\
& $\mathrm{Zr}$ & $1.177 \mathrm{E}+02$ & $\mathrm{Ba}$ & $5.886 \mathrm{E}+01$ \\
& $\mathrm{Mo}$ & $1.112 \mathrm{E}+02$ & $\mathrm{Ru}$ & $7.679 \mathrm{E}+01$ \\
\hline \multirow{2}{*}{ Cladding } & $\mathrm{Cr}$ & $6.022 \mathrm{E}+00$ & $\mathrm{Zr}$ & $4.724 \mathrm{E}+03$ \\
& $\mathrm{Fe}$ & $1.086 \mathrm{E}+01$ & $\mathrm{Sn}$ & $7.722 \mathrm{E}+01$ \\
\hline
\end{tabular}

Table 3. Activities of the Major Elements for the Source Term (PWR 4.5 wt\%, $55 \mathrm{GWd} / \mathrm{tU}, 5$ year cooling, $20 \mathrm{~kg}$ )

\begin{tabular}{lcccc}
\hline & Element & Activity $(\mathrm{Bq})$ & Element & Activity $(\mathrm{Bq})$ \\
\hline \multirow{4}{*}{ Fuel } & $\mathrm{Pu}$ & $1.178 \mathrm{E}+14$ & $\mathrm{Cs}$ & $1.565 \mathrm{E}+14$ \\
& $\mathrm{Am}$ & $1.238 \mathrm{E}+12$ & $\mathrm{Ba}$ & $1.084 \mathrm{E}+14$ \\
& $\mathrm{Cm}$ & $6.656 \mathrm{E}+12$ & $\mathrm{Pm}$ & $3.944 \mathrm{E}+13$ \\
& $\mathrm{Sr}$ & $7.844 \mathrm{E}+13$ & $\mathrm{Rh}$ & $1.913 \mathrm{E}+13$ \\
& $\mathrm{Y}$ & $7.844 \mathrm{E}+13$ & $\mathrm{Rh}$ & $1.913 \mathrm{E}+13$ \\
\multirow{2}{*}{ Cladding } & $\mathrm{Sb}$ & $1.913 \mathrm{E}+13$ & $\mathrm{Co}$ & $1.598 \mathrm{E}+1$ \\
& $\mathrm{Sn}$ & $1.464 \mathrm{E}+11$ & $\mathrm{Te}$ & $7.467 \mathrm{E}+10$ \\
\hline
\end{tabular}


PARK et al., Shielding Performance of a Newly Designed Transport Cask in the Advanced Conditioning Spent Fuel Pyroprocess Facilitiy

Table 4. Neutron Source Distribution (PWR 4.5 wt \%, $55 \mathrm{GWd} / \mathrm{tU}, 5$ year cooling, $20 \mathrm{~kg}$ )

\begin{tabular}{|c|c|c|c|c|}
\hline Group & Lower Energy (eV) & & Upper Energy (eV) & Neutrons/sec \\
\hline 1 & $1.000 \mathrm{E}-11$ & - & $3.000 \mathrm{E}-09$ & $1.985 \mathrm{E}-06$ \\
\hline 2 & $3.000 \mathrm{E}-09$ & - & $7.500 \mathrm{E}-09$ & $4.816 \mathrm{E}-06$ \\
\hline 3 & $7.500 \mathrm{E}-09$ & - & $1.000 \mathrm{E}-08$ & 3.394E-06 \\
\hline 4 & $1.000 \mathrm{E}-08$ & - & $2.530 \mathrm{E}-08$ & $2.881 \mathrm{E}-05$ \\
\hline 5 & $2.530 \mathrm{E}-08$ & - & $3.000 \mathrm{E}-08$ & $1.109 \mathrm{E}-05$ \\
\hline 6 & $3.000 \mathrm{E}-08$ & - & $4.000 \mathrm{E}-08$ & $2.646 \mathrm{E}-05$ \\
\hline 7 & $4.000 \mathrm{E}-08$ & - & $5.000 \mathrm{E}-08$ & $2.996 \mathrm{E}-05$ \\
\hline 8 & $5.000 \mathrm{E}-08$ & - & $7.000 \mathrm{E}-08$ & $6.903 \mathrm{E}-05$ \\
\hline 9 & $7.000 \mathrm{E}-08$ & - & $1.000 \mathrm{E}-07$ & $1.230 \mathrm{E}-04$ \\
\hline 10 & $1.000 \mathrm{E}-07$ & - & $1.500 \mathrm{E}-07$ & $2.483 \mathrm{E}-04$ \\
\hline 11 & $1.500 \mathrm{E}-07$ & - & $2.000 \mathrm{E}-07$ & 2.944E-04 \\
\hline 12 & $2.000 \mathrm{E}-07$ & - & $2.250 \mathrm{E}-07$ & $1.622 \mathrm{E}-04$ \\
\hline 13 & $2.250 \mathrm{E}-07$ & - & $2.500 \mathrm{E}-07$ & $1.715 \mathrm{E}-04$ \\
\hline 14 & $2.500 \mathrm{E}-07$ & - & $2.750 \mathrm{E}-07$ & $1.803 \mathrm{E}-04$ \\
\hline 15 & $2.750 \mathrm{E}-07$ & - & $3.250 \mathrm{E}-07$ & $3.852 \mathrm{E}-04$ \\
\hline 16 & $3.250 \mathrm{E}-07$ & - & $3.500 \mathrm{E}-07$ & $2.043 \mathrm{E}-04$ \\
\hline 17 & $3.500 \mathrm{E}-07$ & - & $3.750 \mathrm{E}-07$ & $2.117 \mathrm{E}-04$ \\
\hline 18 & $3.750 \mathrm{E}-07$ & - & $4.000 \mathrm{E}-07$ & $2.189 \mathrm{E}-04$ \\
\hline 19 & $4.000 \mathrm{E}-07$ & - & $6.250 \mathrm{E}-07$ & $2.260 \mathrm{E}-03$ \\
\hline 20 & $6.250 \mathrm{E}-07$ & - & $1.000 \mathrm{E}-06$ & $4.740 \mathrm{E}-03$ \\
\hline 21 & $1.000 \mathrm{E}-06$ & - & $1.770 \mathrm{E}-06$ & $1.269 \mathrm{E}-02$ \\
\hline 22 & $1.770 \mathrm{E}-06$ & - & $3.000 \mathrm{E}-06$ & $2.660 \mathrm{E}-02$ \\
\hline 23 & $3.000 \mathrm{E}-06$ & - & $4.750 \mathrm{E}-06$ & $4.827 \mathrm{E}-02$ \\
\hline 24 & $4.750 \mathrm{E}-06$ & - & $6.000 \mathrm{E}-06$ & $4.067 \mathrm{E}-02$ \\
\hline 25 & $6.000 \mathrm{E}-06$ & - & $8.100 \mathrm{E}-06$ & $7.821 \mathrm{E}-02$ \\
\hline 26 & $8.100 \mathrm{E}-06$ & - & $1.000 \mathrm{E}-05$ & $8.021 \mathrm{E}-02$ \\
\hline 27 & $1.000 \mathrm{E}-05$ & - & $3.000 \mathrm{E}-05$ & $1.244 \mathrm{E}+00$ \\
\hline 28 & $3.000 \mathrm{E}-05$ & - & $1.000 \mathrm{E}-04$ & $7.861 \mathrm{E}+00$ \\
\hline 29 & $1.000 \mathrm{E}-04$ & - & $5.500 \mathrm{E}-04$ & $1.118 \mathrm{E}+02$ \\
\hline 30 & $5.500 \mathrm{E}-04$ & - & $3.000 \mathrm{E}-03$ & $1.422 \mathrm{E}+03$ \\
\hline 31 & $3.000 \mathrm{E}-03$ & - & $1.700 \mathrm{E}-02$ & $1.920 \mathrm{E}+04$ \\
\hline 32 & $1.700 \mathrm{E}-02$ & - & $2.500 \mathrm{E}-02$ & $1.617 \mathrm{E}+04$ \\
\hline 33 & $2.500 \mathrm{E}-02$ & - & $1.000 \mathrm{E}-01$ & $2.518 \mathrm{E}+05$ \\
\hline
\end{tabular}




\begin{tabular}{l|lll|l}
\hline 34 & $1.000 \mathrm{E}-01$ & - & $4.000 \mathrm{E}-01$ & $1.818 \mathrm{E}+06$ \\
35 & $4.000 \mathrm{E}-01$ & - & $9.000 \mathrm{E}-01$ & $3.965 \mathrm{E}+06$ \\
36 & $9.000 \mathrm{E}-01$ & - & $1.400 \mathrm{E}+00$ & $3.960 \mathrm{E}+06$ \\
37 & $1.400 \mathrm{E}+00$ & - & $1.850 \mathrm{E}+00$ & $3.164 \mathrm{E}+06$ \\
38 & $1.850 \mathrm{E}+00$ & - & $2.350 \mathrm{E}+00$ & $2.970 \mathrm{E}+06$ \\
39 & $2.350 \mathrm{E}+00$ & - & $2.480 \mathrm{E}+00$ & $6.413 \mathrm{E}+05$ \\
40 & $2.480 \mathrm{E}+00$ & - & $3.000 \mathrm{E}+00$ & $2.285 \mathrm{E}+06$ \\
41 & $3.000 \mathrm{E}+00$ & - & $4.800 \mathrm{E}+00$ & $4.168 \mathrm{E}+06$ \\
42 & $4.800 \mathrm{E}+00$ & - & $6.430 \mathrm{E}+00$ & $1.193 \mathrm{E}+06$ \\
43 & $6.430 \mathrm{E}+00$ & - & $8.190 \mathrm{E}+00$ & $3.794 \mathrm{E}+05$ \\
44 & $8.190 \mathrm{E}+00$ & - & $2.000 \mathrm{E}+01$ & $1.309 \mathrm{E}+05$ \\
\hline
\end{tabular}

Table 5. Photon Source Distribution (PWR 4.5 wt\%, 55 GWd/tU, 5 year cooling, $20 \mathrm{~kg}$ )

\begin{tabular}{c|ccc|c}
\hline Group & Lower energy $(\mathrm{eV})$ & Upper energy $(\mathrm{eV})$ & Photons/sec \\
\hline 1 & $1.00 \mathrm{E}-02$ & - & $5.00 \mathrm{E}-02$ & $7.764 \mathrm{E}+13$ \\
2 & $5.00 \mathrm{E}-02$ & - & $1.00 \mathrm{E}-01$ & $2.209 \mathrm{E}+13$ \\
3 & $1.00 \mathrm{E}-01$ & - & $2.00 \mathrm{E}-01$ & $1.807 \mathrm{E}+13$ \\
4 & $2.00 \mathrm{E}-01$ & - & $3.00 \mathrm{E}-01$ & $5.111 \mathrm{E}+12$ \\
5 & $3.00 \mathrm{E}-01$ & - & $4.00 \mathrm{E}-01$ & $3.513 \mathrm{E}+12$ \\
6 & $4.00 \mathrm{E}-01$ & - & $6.00 \mathrm{E}-01$ & $4.463 \mathrm{E}+13$ \\
7 & $6.00 \mathrm{E}-01$ & - & $8.00 \mathrm{E}-01$ & $1.378 \mathrm{E}+14$ \\
8 & $8.00 \mathrm{E}-01$ & - & $1.00 \mathrm{E}+00$ & $1.980 \mathrm{E}+13$ \\
9 & $1.00 \mathrm{E}+00$ & - & $1.33 \mathrm{E}+00$ & $5.515 \mathrm{E}+12$ \\
10 & $1.33 \mathrm{E}+00$ & - & $1.66 \mathrm{E}+00$ & $1.672 \mathrm{E}+12$ \\
11 & $1.66 \mathrm{E}+00$ & - & $2.00 \mathrm{E}+00$ & $5.966 \mathrm{E}+10$ \\
12 & $2.00 \mathrm{E}+00$ & - & $2.50 \mathrm{E}+00$ & $1.129 \mathrm{E}+11$ \\
13 & $2.50 \mathrm{E}+00$ & - & $3.00 \mathrm{E}+00$ & $4.257 \mathrm{E}+09$ \\
14 & $3.00 \mathrm{E}+00$ & - & $4.00 \mathrm{E}+00$ & $3.951 \mathrm{E}+08$ \\
15 & $4.00 \mathrm{E}+00$ & - & $5.00 \mathrm{E}+00$ & $8.689 \mathrm{E}+05$ \\
16 & $5.00 \mathrm{E}+00$ & - & $6.50 \mathrm{E}+00$ & $3.487 \mathrm{E}+05$ \\
17 & $6.50 \mathrm{E}+00$ & - & $8.00 \mathrm{E}+00$ & $6.841 \mathrm{E}+04$ \\
18 & $8.00 \mathrm{E}+00$ & - & $1.00 \mathrm{E}+01$ & $1.452 \mathrm{E}+04$ \\
\hline
\end{tabular}


energy (DE) and dose function (DF) cards are used to obtain the neutron and gamma dose rates quoted from ICRP-74(1995). For the gamma ray shielding calculation, the weighted window method was implemented to reduce the variance [9]. The secondary photon was also tallied from the neutron induced reaction.

Every MCNPX problem has one the following four sources: general source (SDEF card), criticality source (KCODE card), surface source (SSR card), or usersupplied source. Each of these can use source distribution functions, specified for a source information (SI) card, a source probability (SP) card, a source bias (SB) card, and a dependent source distribution (DS) card [5]. In this calculation, a general source definition (SDEF) card is used to specify the positions of the different rod-cuts. In the general source variables of the SDEF card, an energy variable (ERG), a reference point for a position sampling (POS), a radial distance of the position from POS (RAD), and an extension from the reference position along the $Z$ axis (EXT) are specified by the source information (SI) card. The neutron and gamma energies of the source term obtained by the ORIGEN-ARP are provided as discrete source energies in the SI card for the ERG variables. Their corresponding probabilities are also given in the SP card with the D option. The inventory of the source term evaluated by the ORIGEN-ARP is used for a material specification (M) card.

For the cross-section libraries of MCNPX, the continuous energy libraries of RMCCS and ENDF60 which are based on ENDF/B-V and ENDF/B-VI, respectively, are used for the neutron calculation, and MCPLIB04 is used for the gamma calculation. The temperatures of the libraries are evaluated at $293.6 \mathrm{~K}$.

\section{RESULTS AND DISCUSSION}

The new hot cell cask was modeled in detail, as shown in Fig. 3, in order to perform a shielding calculation with the MCNPX code. The fuel rod cuts were arranged in the center with two layers, and they were contained in a cylindrical Al cask. Table 6 shows the results of the shielding calculation for the new hot cell cask with the two shielding materials. The maximum dose rates were estimated when using polyethylene as $0.552 \mathrm{mSv} / \mathrm{hr}$, $0.420 \mathrm{mSv} / \mathrm{hr}$, and $0.473 \mathrm{mSv} / \mathrm{hr}$ on the side, bottom, and top surfaces of the new hot cell cask, respectively. When using resin, the maximum dose rates were estimated as $0.838 \mathrm{mSv} / \mathrm{hr}, 0.666 \mathrm{mSv} / \mathrm{hr}$, and $0.701 \mathrm{mSv} / \mathrm{hr}$ on the side, bottom, and top surfaces, respectively. All the dose rates were estimated as lower than $2 \mathrm{mSv} / \mathrm{hr}$, which is the limit for a radioactive material transport cask [10]. We also obtained a dose rate at $2 \mathrm{~m}$ apart from the surface of the transport cask. In the case of polyethylene, 0.010 $\mathrm{mSv} / \mathrm{hr}$ was obtained, and in the case of resin, 0.022 $\mathrm{mSv} / \mathrm{hr}$ was obtained, which were well within the limit of $0.1 \mathrm{mSv} / \mathrm{hr}$. Accident conditions assumed the absence of an outer neutron shield. The dose analysis covers the

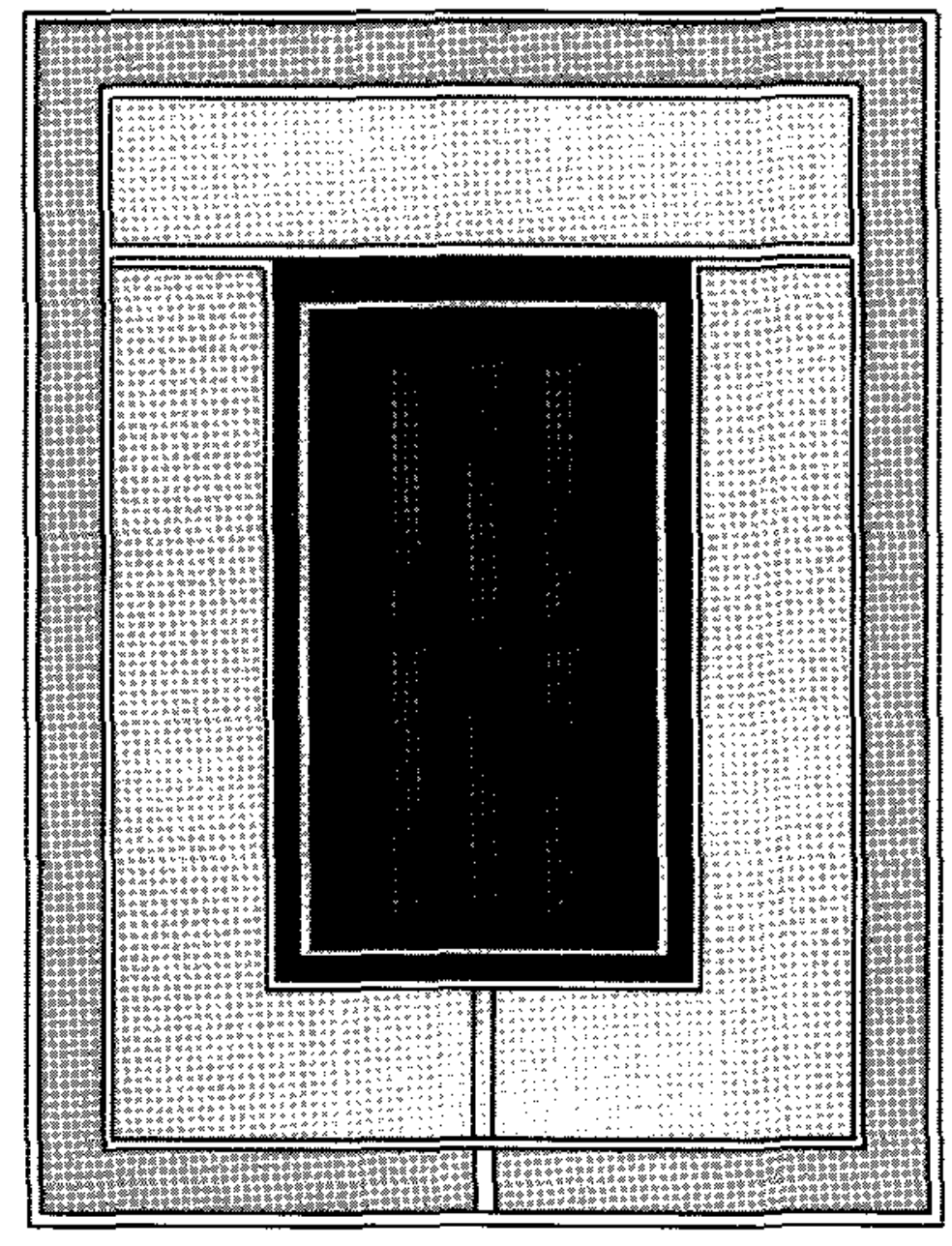

(a)

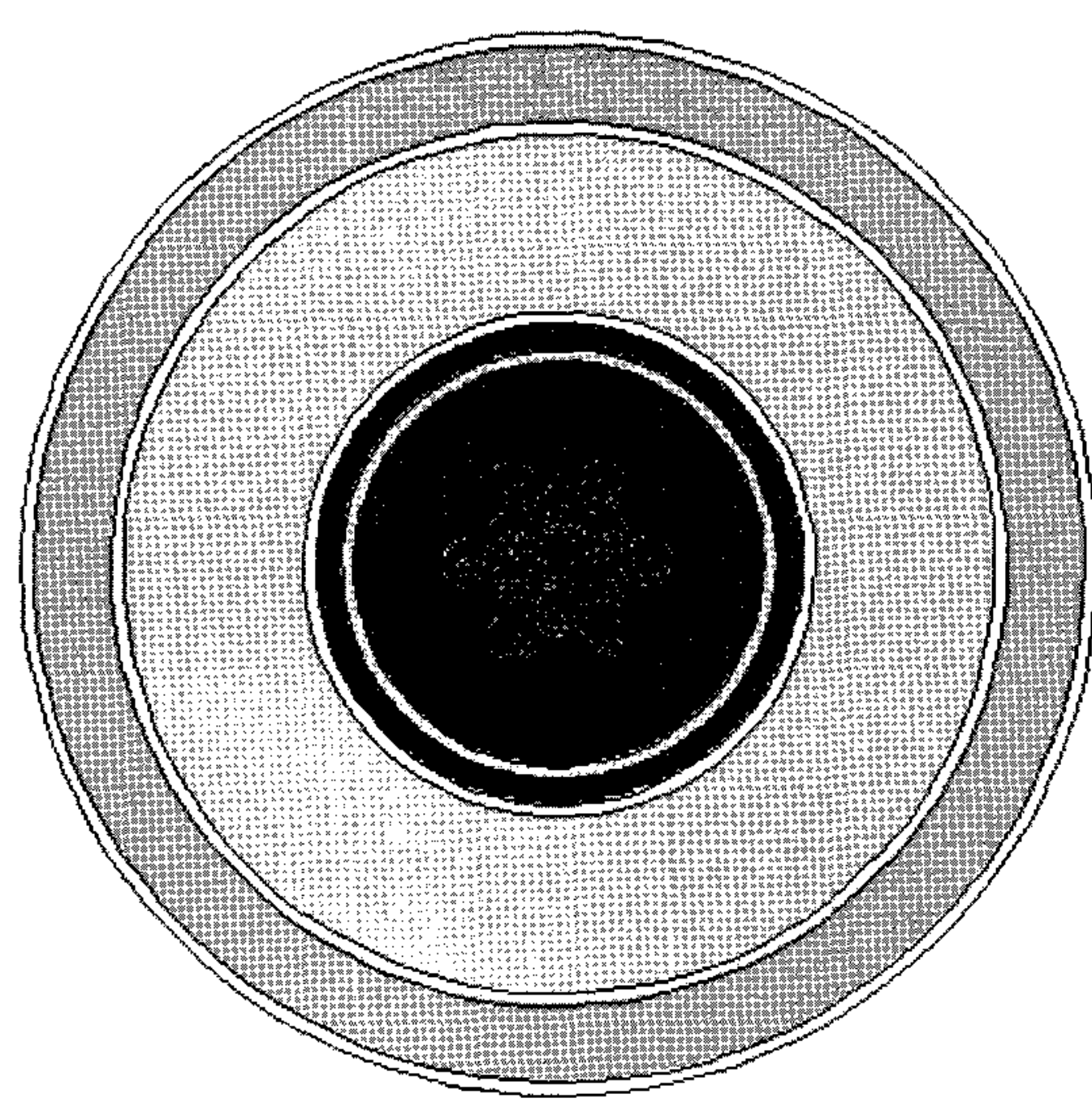

(b)

Fig. 3. MCNP Model for the Hot Cell Cask

(a) Vertical View (xz-direction), (b) Horizontal View (xy-direction) 
Table 6. Surface Dose Rate from the Shielding Calculation by MCNPX (unit: mSv/hr)

\begin{tabular}{|c|c|c|c|c|c|}
\hline & Tally & Side & Bottom & Top & $2 \mathrm{~m}$ \\
\hline \multirow{4}{*}{ Polyethylene } & Neutron & $\begin{array}{c}3.28 \mathrm{E}-01 \\
( \pm 8.19 \mathrm{E}-4)^{*}\end{array}$ & $\begin{array}{c}3.04 \mathrm{E}-01 \\
( \pm 7.92 \mathrm{E}-03)\end{array}$ & $\begin{array}{c}2.50 \mathrm{E}-01 \\
( \pm 7.04 \mathrm{E}-03)\end{array}$ & $\begin{array}{c}5.78 \mathrm{E}-03 \\
( \pm 2.37 \mathrm{E}-05)\end{array}$ \\
\hline & Secondary photon & $\begin{array}{c}1.79 \mathrm{E}-02 \\
( \pm 3.17 \mathrm{E}-4)\end{array}$ & $\begin{array}{c}1.47 \mathrm{E}-02 \\
( \pm 5.22 \mathrm{E}-04)\end{array}$ & $\begin{array}{c}1.29 \mathrm{E}-02 \\
( \pm 5.25 \mathrm{E}-04)\end{array}$ & $\begin{array}{c}2.86 \mathrm{E}-04 \\
( \pm 1.46 \mathrm{E}-06)\end{array}$ \\
\hline & Photon & $\begin{array}{c}2.06 \mathrm{E}-01 \\
( \pm 6.31 \mathrm{E}-3)\end{array}$ & $\begin{array}{c}1.01 \mathrm{E}-01 \\
( \pm 1.42 \mathrm{E}-02)\end{array}$ & $\begin{array}{c}2.10 \mathrm{E}-01 \\
( \pm 1.24 \mathrm{E}-02)\end{array}$ & $\begin{array}{c}3.69 \mathrm{E}-03 \\
( \pm 1.50 \mathrm{E}-04)\end{array}$ \\
\hline & Total & $\begin{array}{c}5.52 \mathrm{E}-01 \\
( \pm 6.37 \mathrm{E}-03)\end{array}$ & $\begin{array}{c}4.20 \mathrm{E}-01 \\
( \pm 1.63 \mathrm{E}-02)\end{array}$ & $\begin{array}{c}4.73 \mathrm{E}-01 \\
( \pm 1.43 \mathrm{E}-02)\end{array}$ & $\begin{array}{c}9.76 \mathrm{E}-03 \\
( \pm 1.52 \mathrm{E}-04)\end{array}$ \\
\hline \multirow{4}{*}{ Resin } & Neutron & $\begin{array}{c}6.40 \mathrm{E}-01 \\
( \pm 1.15 \mathrm{E}-03)\end{array}$ & $\begin{array}{c}5.66 \mathrm{E}-01 \\
( \pm 1.09 \mathrm{E}-02)\end{array}$ & $\begin{array}{c}4.73 \mathrm{E}-01 \\
( \pm 9.93 \mathrm{E}-03)\end{array}$ & $\begin{array}{c}1.80 \mathrm{E}-02 \\
( \pm 5.76 \mathrm{E}-05)\end{array}$ \\
\hline & Secondary photon & $\begin{array}{c}1.00 \mathrm{E}-02 \\
( \pm 2.27 \mathrm{E}-04)\end{array}$ & $\begin{array}{c}7.46 \mathrm{E}-03 \\
( \pm 3.34 \mathrm{E}-04)\end{array}$ & $\begin{array}{c}6.45 \mathrm{E}-03 \\
( \pm 3.27 \mathrm{E}-04)\end{array}$ & $\begin{array}{c}1.66 \mathrm{E}-04 \\
( \pm 9.99 \mathrm{E}-07)\end{array}$ \\
\hline & Photon & $\begin{array}{c}1.88 \mathrm{E}-01 \\
( \pm 5.19 \mathrm{E}-03)\end{array}$ & $\begin{array}{c}9.22 \mathrm{E}-02 \\
( \pm 6.42 \mathrm{E}-03)\end{array}$ & $\begin{array}{c}2.22 \mathrm{E}-01 \\
( \pm 1.53 \mathrm{E}-02)\end{array}$ & $\begin{array}{c}3.42 \mathrm{E}-03 \\
( \pm 9.05 \mathrm{E}-05)\end{array}$ \\
\hline & Total & $\begin{array}{c}8.38 \mathrm{E}-01 \\
( \pm 5.32 \mathrm{E}-03)\end{array}$ & $\begin{array}{c}6.66 \mathrm{E}-01) \\
( \pm 1.27 \mathrm{E}-02\end{array}$ & $\begin{array}{c}7.01 \mathrm{E}-01 \\
( \pm 1.82 \mathrm{E}-02)\end{array}$ & $\begin{array}{c}2.16 \mathrm{E}-02 \\
( \pm 1.07 \mathrm{E}-04)\end{array}$ \\
\hline
\end{tabular}

* standard deviation

accident conditions in 10CFR71.73 in a conservative manner because a complete loss of a neutron shield is not possible. The outer neutron shield is replaced by air. One meter from the surface of the transport cask, a dose rate of $0.105 \mathrm{mSv} / \mathrm{hr}$ was obtained, which lies below the limit of $10 \mathrm{mSv} / \mathrm{hr}$. The reasons for the low dose rate for the accident conditions are that the activity of the source term is sufficiently low and that the inner shielding materials maintain their integrity. From the results, polyethylene provides a better shielding capability among the two shielding materials, and resin also provides an alternative shielding material. From the detailed design of the new hot cell cask, additional tests such as thermal and mechanical analyses should be performed. By integrating all the analyses for the new hot cell transport cask, an optimal material will be chosen not only for its shielding capability, but also for absorbing shock.

To design a new transport cask, criticality analyses should be followed. From the preliminary results, the effective multiplication factors were estimated as 0.16606 \pm 0.00071 and $0.16915 \pm 0.00073$ for polyethylene and resin, respectively. A detailed evaluation for their criticality will be given in another paper.

\section{CONCLUSION}

The Monte Carlo shielding calculations were performed using the MCNPX code for the design concept for a new hot cell transport cask in the ACPF. The source term was determined using a PWR spent fuel from the results of the ORIGEN-ARP code. Neutron and gamma ray shielding capabilities were compared for two kinds of shielding materials, polyethylene and resin. All the materials provided satisfactory shielding capabilities within the limit of the surface dose rates. It is expected that we can choose an optimal material from the results of additional detailed analyses, including thermal and mechanical simulations for the new hot cell transport cask in the ACPF.

\section{ACKNOWLEDGEMENTS}

This work has been carried out under the Nuclear Research and Development program of the Korea Ministry of Science and Technology.

\section{REFERENCES}

[ 1 ] J.J. Laidler, J.E. Battles, W.E. Miller, J.P. Ackerman, and E.L. Carls, "Development of Pyroprocessing Technology," 
Prog. in Nucl. Energy, 31,131-140(1997).

[2] T.H. Lee, H.D. Kim, K.J. Jung, and S.W. Park, "Development of a Neutron Coincidence Counter for the Advanced Spent Fuel Conditioning Process," J. Ko. Phys. Soc., 48, 218-221 (2006).

[3] webpage, www.lacalhene.com.

[4] K. Ueki, K. Kawakami, D. Shimizu, "Using the Monte Carlo Coupling Technique to Evaluate the Shielding Ability of a Modular Shielding House to Accommodate Spent-Fuel Transportable Storage Casks," Nucl. Tech., 141, 177-185 (2003).

[ 5 ] D.B. Pelowitz, ed., MCNPX User's Manual, LA-CP-050369, Los Alamos National Laboratory, 2005.

[ 6 ] I.G. Gauld, S.M. Bowman, J.E. Horwedel, and L.C. Leal,
ORIGEN-ARP: Automatic Rapid Processing for Spent Fuel Depletion, Decay, and Source Term Analysis, ORNL/ NUREG/CSD-2/V1/R7, 2004.

[7] E.E. Lewis and W.F. Miller, Jr., Computational Methods of Neutron Transport, John Wiley \& Sons, 1984

[ 8 ] J. Spanier and M. Gelbard, Monte Carlo Principles and Neutron Transport Problems, Addison-Wesley Publishing Company, London, 1969.

[9] T.E. Booth, A Sample Problem for Variance Reduction in MCNP, LA-10363-MS, Los Alamos National Laboratory, 1985.

[10] US NRC, Standard Review Plan for Transportation Packages for Spent Nuclear Fuel, NUREG-1617, March 2000 . 